\title{
RECEIVERS AND LEASES SUBORDINATE TO THE MORTGAGE
}

\author{
SHELDON TEPFT*
}

QUESTION which must frequently arise in the foreclosure of
mortgages (including trust deeds) of real property is the effect of
the appointment of a receiver upon leases which are subordinate to the mortgage. This question is important not only to the tenants and the receiver, but also to the mortgagee, the mortgagor, junior lienholders and assignees of the equity of redemption. Though the courts have been flooded with receivership cases, a search of the reports discloses comparatively few cases in which the problem has been considered. The object of this essay is an examination of foreclosure receiverships to determine the effect of a receivership upon leases of the mortgagor which are subordinate to the mortgage which is being foreclosed.

\section{NATURE OF FORECLOSURE RECETVERSHIP}

A foreclosure receivership is an institution of the court of chancery designed to preserve the mortgagee's security in order that it will be available when the suit is ended. Just as the court of chancery will protect the mortgagee by enjoining acts endangering his margin of security so, pending the foreclosure suit, it will assume custody of the property when its assistance is needed to prevent irreparable injury, and will delegate an officer of the court to do those things proper to insure that the property pledged as security will be available when the decree has been obtained. The court undertakes this formidable task only because its aid is essential to prevent threatened irreparable injury to the mortgagee. It is not undertaken simply because the mortgagee has a right to possession or a contract for a receiver pending foreclosure. ${ }^{2}$ Unless the mortgagee can show

* Associate Professor of Law, University of Chicago.

× 2 Daniell, Chancery Pleading and Practice (6 Am. ed. I894), ${ }^{*}$ ×7 5 et seq. especially $\S$ I7 6 note (b); 4 Pomeroy, Equity Jurisprudence (3d ed. I9r9), § r33o; Clark, Receivers (2d ed. I929), § 24; High, Receivers (3d ed. r894), § x; 3 Jones, Mortgages (8th. ed. I928), § r930; Wyatt Practical Register ( 1800 ), $\$ 355$. For a typical judicial statement see Chicago Title and Trust Co. v. Mack, 347 Ill. 480, 483, I80 N.E. 4I2, 4I3 (I932).

2 Frank v. Siegel, 263 Ill. App. 3 I6 (I93I); Aetna Life Insurance Co. v. Broeker, I66 Ind. 576, 77 N.E. Iog2 (I906); Lackey v. Yekel, Ir3 Neb. 382 , 203 N.W. 542 (r925); cf. Bagley v. IIl. Trust and Sav. Bank, I99 III. 76, 64 N.E. 1085 (1902); Tucker v. Nabo Construction Corp., I08 N.J. Eq. 449, I55 Atl. 623 (I93I); note: 4 A.L.R. I4r5 (I9rg); 55 A.L.R. I027 (I928); 87 A.L.R. 635 (r933). 
a genuine danger that his security will become inadequate and that in this event his remedies on the debt will be inadequate, the court will not ordinarily undertake the management of the property. But when such a showing is made, the court does not hesitate to undertake the preservation of the security and will order the receiver to do all things reasonably necessary to accomplish this purpose. Not only does the court through its officer assume the normal incidents of management, but in exceptional cases it may resort to more unusual expedients such as the continuance of the mortgagor's business ${ }^{3}$ or the issuance of receiver's certificates which may displace the lien of the mortgage being foreclosed. ${ }^{4}$ The court has developed too, the theory that the property is in custodia legis and that any unauthorized interference with the receivership either, directly, by interfering with the receiver's possession, or, indirectly, by the institution of actions or process relating to the property is a contempt of court..$^{5}$ In

3 Cake v. Mohun, I64 U.S. 3 II (I896); First National Bank of San Francisco v. Detroit Trust Co., 248 Fed. I6 (C.C.A. 9th I9r6) (consent); Pacific Northwest Packing Co. v. Allen, rog Fed. 5 I5 (C.C.A. gth IgoI); Makeel v. Hotchkiss, I9O Ill. 3II, 60 N.E. 524 (Igor) (consent); note: I4 St. Louis $\mathrm{L}$. Rev. 3I5 (Ig29). An analogous problem is the power of the court to appoint a receiver for property not included in the mortgage. It is generally stated that the court has no "jurisdiction" to appoint a receiver of property not covered by the mortgage. Scott v. Farmers' Loan and Trust Co., 69 Fed. $x_{7}$ (C.C.A. 8th I895); Noyes v. Rich, 52 Maine, II5 (I862); Thomas v. Armstrong, 5I Okla. 203, I5I Pac. 689 (rgI5); Whitley v. Challis, [r892] I Ch. 64. The results of these cases are doubtless correct because the petitioners failed to show that the preservation of their security necessitated control by the receiver of the unmortgaged property. Had such a showing been made, the denial of the receivership seems questionable. See Grant v. Leach \& Co., 280 U.S. 35 I (r930), reversing Leach \& Co. v. Grant 27 Fed. (2d) $20 x$ (C.C.A. 6th I928); Sumsion v. Crutwell, 3 I W.R. 399 (Ch. I883); Campbell v. Iloyd's Bank, 58 L.J. 424 (Ch. I889); County of Gloucester Bank v. Rudry Methyr Steam and House Coal Colliery Co., [I895] I Ch. 629, 638; I Tardy's Smith on Receivers (2d ed. I920), 577; note ${ }_{4}$ St. Louis L. Rev. 3 I 5 (Ig29). The fear that if a receiver is appointed, the unmortgaged property will not be available for the other creditors of the mortgagor (see Thomas v. Armstrong, $5 \mathrm{I}$ Okla. 203, I5 I Pac. 689 [I9I5]) seems groundless, since in the final account the priority of the mortgagee might be limited to that portion of the assets derived from the mortgaged property.

4 Colorado Wool Marketing Assn. v. Monaghan, 66 F. (2d) 313 (C.C.A. Ioth 1933); Feldman v. Am. Palestine Line, Inc., I5 F. (2d) 94, (D.C. N.Y. 1926); Title Insurance and Trust Co. v. California Development Co., I7I Cal. 227, I52 Pac. 542 (xgr5); Lockport Felt Co. v. United Box Board and Paper Co., 74 N.J. Eq. 686, 7o Atl. 980 (rgo8); Porch v. Agnew Co., 57 Atl. 546 (N.J. Eq. I904); Lunsky v. Criterion Construction Co., 151 Atl. 490 (N.J. Eq. I930). The jurisdiction is exercised cautiously and the courts are reluctant to displace the mortgagee's priority to obtain funds required to continue the business: Hanna v. State Trust Co., 70 Fed. 2 (C.C.A. 8th I895); Raht v. Attrill, Io6 N.Y. 423, I3 N.E. 282 (I887); Rhode Island Hospital Trust Co. v. Greene and Sons Corp., 50 R.I. 305, I46 Atl. 765 (I929); see notes: 3I Col. L. Rev. I70 (I93I); 7 Mich. L. Rev. 239 (I909); 79 U. of Pa. L. Rev. 788 (I93I).

5 Wiswall v. Sampson, I4 How. (U.S.) 52 (I852); People v. Kowalski, 307 Ill. 378 , r38 N.E. 634 (I923); Anderson v. Macek, 350 Ill. I35, I82 N.E. 745 (1932); Angel v. Smith, 9 Ves. 335 (I804); 4 Pomeroy, Equity Jurisprudence (4th ed. I9I9), $\$$ I583-I590; I 7 Minn. L. Rev. 560 (r933). 
short, the theory of the receivership is that it is a conservation measure designed to protect the interests of all parties to the proceeding pending the determination of the suit, and that it is the function of the receiver acting under the instructions of the court to do those things reasonably necessary to accomplish this fundamental end.

This, then, brings one to the immediate problem: what are the rights and duties of receivers with respect to tenants of the mortgagor whose leases are subordinate to the mortgage? If the terms of the mortgagor's leases are as advantageous as those which the receiver could negotiate, may he affirm them? If the terms are not substantially as good as he could obtain may he repudiate them? Or, to state the problem from the point of view of the tenants: what are the rights and duties of the tenants? If the terms are advantageous, may the tenants enforce the leases against the receiver? If the terms are burdensome may the tenants avoid the leases upon the appointment of the receiver? The answer to these problems depends, it is submitted, upon the answer to a simple question: can the mortgagee's margin of security be preserved adequately without avoiding the mortgagor's leases? If the margin of security can be adequately preserved the tenants should not be disturbed, because a receivership should not alter the status quo more than is necessary to accomplish this end. ${ }^{6}$ But when the margin of security cannot be preserved adequately if the mortgagor's leases are continued, the court should direct the receiver to repudiate them and negotiate new ones.

To apply this principle to a specific case, the court must determine whether the rents and profits pending foreclosure as well as the corpus constitute a part of the mortgagee's security. If they do not, the receiver should not avoid the mortgagor's leases even though the rents reserved are much lower than the receiver might obtain for new leases. Unless the possession of the tenants endangers the corpus, they should be permitted to continue under their old leases. If, however, rents and profits pending foreclosure constitute a portion of the mortgagee's security, the court must determine whether the continuance of the mortgagor's leases will render the mortgagee's margin of security inadequate. If it will, the receiver should be directed to avoid the mortgagor's leases. Approached

${ }^{6}$ In re Newdigate Colliery, Ltd., [19I2] I Ch. 468; In re Great Cobar, Ltd., [19I5] I Ch. 682; Stamer v. Nisbitt, 9 Ir. Eq. R. 96 (1846) (order for sale free from mortgagor's leases refused, but referred to master to ascertain whether mortgagee's security was inadequate); Murtin v. Walker, Sau. \& Sc. I39 (Ir. Rolls I837) (court refused to evict mortgagor's tenants because no showing of inadequacy of mortgagee's security and doubts as to validity of the mortgage); American Brake Shoe \& Foundry Co. v. N.Y. Railroad Co., 278 Fed. 842 (D.C.N.Y. I922). Cf. the rule of "sale in inverse order of alienation": 3 Jones, Mortgages (8th ed. I928), \$ 2084. 
from this point of view the results of the cases in which the question has been raised seem reasonable.

\section{RIGHT OF RECEIVER TO DISAFFIRM MORTGAGOR'S IEASES}

In "title" jurisdictions in which the mortgagee qua mortgagee is entitled to possession from and after default, rents and profits constitute a part of his security and in those jurisdictions the courts order receivers to disaffirm the mortgagor's leases in which the rent reserved is less than the reasonable value of the premises if the continuation of those leases endangers the mortgagee's margin of security. ${ }^{7}$

In "lien" jurisdictions where the mortgagee qua mortgagee is not entitled to possession and the rents and profits are not a part of the mortgagee's security, the courts order receivers not to interfere with the mortgagor's leases even though the rents reserved are less than the receiver might get for new leases. ${ }^{8}$ Conceivably in a "lien" jurisdiction though the mortgagee is not entitled to possession pending the suit, he may, by reason of a pledge of rents or some theory of equitable lien, have some claim to rents and profits pending foreclosure. ${ }^{8 a}$ The extent of this right depends upon the statutes and decisions of the particular jurisdiction. The mortgagee may be entitled to the occupational value of the premises during the suit or his right may be limited to the rents which actually accrue under the mortgagor's leases during the suit. Whether in a "lien" jurisdiction, then, the receiver may disaffirm the mortgagor's leases, depends upon the view adopted as to the extent of the mortgagee's security. If the security includes the occupational value of the premises, the receiver may avoid. those leases of the mortgagor the continuance of which will endanger the mortgagee's margin of security;' if it does not include rents and profits or if it includes only those rents which in fact accrue under the mortgagor's

7 Rohrer v. Deatherage, 336 Ill. 450, I68 N.E. 266 (1929); The Rankin-Whitham State Bank v. Mulcahey, 344 Ill. 99 , I 76 N.E. 366 (r93r); Henshaw Ward \& Co. v. Wells, 9 Humph. (Tenn.) 568 ( 1848 ); Lord Mansfield v. Hamilton, 2 Sch. \& Lef. 28 (Ch. 1804) (leases subordinate to mortgage apparently held unenforceable against the receiver). The cases permitting receivers to avoid the mortgagor's arrangements for payment of rent in advance of the date it is due may be supported on this ground. See Boteler v. Leber, rr2 N.J. Eq. 44 I, r64 Atl. 572 (I933).

8 Motor Finance Co. v. Wenzlaff, 197 Iowa 314, I97 N.W. 60 (I924); Smith v. Cushatt, 199 Iowa 690, 202 N.W. 548 (1925); The Prudence Co. Inc. v. I6o W. 73rd St. Corp., 260 N.Y. 205, I83 N.E. $3^{6} 5$ (I932); Grether v. Nick, r93 Wis. 503, 2r3 N.W. 304 (I927); Ottman v. Tilbury, 204 Wis. 56, 234 N.W. 325 (1931); Zimmerman v. Walgreen, 255 N.W. 534 (Wis. I934).

8a Bank of Manhattan Trust Co. v. 57 I Park Ave. Corp., 263 N.Y. 57, I88 N.E. I56 (r933).

9 State ex rel. Coker v. Dist. Court of Tulsa County, I59 Okla. ro, Ir P. (2d) 495 (I932). 
leases, the receiver is bound by those leases unless they can be impeached as fraudulent or unless their continuance endangers the corpus of the property. ${ }^{\text {o }}$

\section{RIGHT TO AFFIRM MORTGAGOR'S IEASES}

Normally the rent reserved in leases negotiated by the mortgagor before foreclosure will be higher than the receiver can obtain for new leases. For not only will the foreclosure ordinarily be commenced when real estate values are depressed, but the receiver's leases will of necessity be forced transactions negotiated under most unfavorable circumstances. ${ }^{x \mathbf{x}}$ Unless, therefore, the mortgagor's leases were executed under special circumstances, as, for example, co-operative apartment leases or by a desperate or fraudulent mortgagor, the terms will be more favorable than the receiver can obtain. The receiver will usually, therefore, desire to affirm rather than disaffirm the mortgagor's leases. The tenants, however, will be anxious to repudiate them as improvident bargains. Since the purpose of the receivership is to preserve the property which is the subject of the suit, it would seem that the tenants should not be permitted to rely upon the appointment of the receiver as a release from these undesirable leases. And yet, strangely enough, the device developed by the court of chancery as a conservation measure has been seized upon by tenants to justify a repudiation of unfavorable leases. In jurisdictions where the receiver is bound by the mortgagor's leases their efforts have failed. ${ }^{12}$ In jurisdictions where the receiver may repudiate the mortgagor's leases the question has seldom been considered. ${ }^{13}$ The argument for the tenants in those jurisdictions is based upon two grounds: one, want of privity of estate between the receiver and the tenants, and two, unfairness.

ro The Prudence Co. v. r6o W. 73rd St. Corp., 260 N.Y. 205, 183 N.E. 365 (1932).

II For cases illustrating some of the difficulties, see Chicago Deposit Vault v. McNutla, I53 U.S. 554 (I894); Farmers Loan \& Trust v. Eaton, II4 Fed. I4 (C.C.A. 8th Igo2); Gooden v. Vinke, 87 IIl. App. 562 (I899); Chicago Land Bank v. McCambridge, 343 IIl. 456, I 75 N.E. 834 (1931); Shreve v. Hankinson, 34 N.J. Eq. 413 (r88I); Weeks v. Weeks and Cornwell, ro6 N.Y. 626, I3 N.E. 96 (I887).

${ }^{2}$ Loring M. Hewen Co. v. Malter, 260 N.Y.S. 624, I45 Misc. 635 (1932); Metropolitan Life Ins. Co. v. Childs Co., 230 N.Y. 285 , I30 N.E. 295 (I92I); Markantonis v. Madlan Realty Corp., 262 N.Y. 354, 186 N.E. 862 (I933); Knickerbocker Oil Corp. v. Richfield Oil Corp., 254 N.Y.S. 506, 234 App. Div. I99 (I93I); note, 33 Col. L. Rev. I2II (I933); for an extreme case see Lynch v. Harrer, 26I N.Y.S. 565, I46 Misc. 493 (1933).

${ }^{2}$ Cases commonly cited for this point are not in point. See, for example, Stephen v. Reibling, 45 Ill. App. 40 (1892) in which the tenant did not, apparently, contest liability for rent. It was recently considered by the New Jersey Chancery Court: Walgreen v. Moore, I73 Atl. 587 (N.J. 1934). 


\section{WANT OF PRIVITY OF ESTATE}

The tenants contend that the position of the receiver is substantially that of a mortgagee in possession; that a mortgagee in possession cannot for want of privity of estate enforce the leases of his mortgagor ${ }^{\mathrm{T}}$ and that, therefore, upon the appointment of a receiver, the mortgagor's tenants may repudiate their.leases. The premise that the receiver occupies the position of a mortgagee in possession is supported, the tenants contend, by the facts that the receiver is not bound by the mortgagor's leases, that he is appointed upon the motion of the mortgagee, and that the funds collected by the receiver are applied to satisfy the mortgagee's claims.

In considering this argument several points should be noted. In the first place, the assumption that the receiver can avoid the mortgagor's leases because his position is substantially that of a mortgagee in possession is not consistent with the fundamental nature of receiverships in foreclosure cases. As has already been developed, the receiver is an officer of the court appointed to conserve the mortgagee's security until the determination of the foreclosure proceedings. ${ }^{\mathrm{IS}} \mathrm{He}$ is the representative not of the mortgagee but of all parties to the suit. His rights are not dependent upon the title of the mortgagee. He is not chosen by the mortgagee. He is not subject to the control of the mortgagee. The mortgagee is not liable. for his defaults. ${ }^{16}$ A right of the mortgagee to possession either qua mortgagee or by express agreement will not per se induce the chancellor to appoint a receiver. ${ }^{17}$ Even though the mortgagee's right to possession is unconditional and his security is inadequate a receiver will not be appointed if the mortgagor furnishes security which is satisfactory to the court. ${ }^{18}$ Moreover, a receiver is appointed in many cases in which the mortgagee is not entitled to possession. A receivership is just as common in a "lien"

${ }^{{ }_{4}} 3$ Tiffany, Real Property (2d ed. 1920), 2447.

rs See Central Trust Co. v. Worcester Cycle Co., 93 Fed. 7r2 (C.C.A. $2 d$ I89g), rro Fed. $49 \mathrm{r}$ (C.C.A. Mass. Igor), II 4 Fed. 660 (C.C.A. I902); and 24 Halsbury Laws of England, Receivers (I912), $\S 722$, p. 384 .

${ }^{16}$ Rigge v. Bowater, 3 Bro. C. C. 365 ( I79I); Hutchinson v. Massareene, 2 Ball \& B. 49,55 (r8rr); Ingham v. Sutherland, 63 L. T. $6 \mathrm{I}_{4}$ (Ch. I89o); Robinson v. Arkansas Loan and Trust Co., 74 Ark. 292, 85 S.W. 4I3 (I905); Kaiser v. Kellar, 2I Iowa 95 (1866); Farmers Loan and Trust Co. v. Oregon Pac. Rd., 3I Ore. 237, 48 Pac. 706 (1897). Cf. Sorchan v. Mayo, 50 N.J. Eq. 288, 23 Atl. 479 (1892). See 3 Jones, Mortgages (8th ed. 1928), $\$$ I954. For the analogous problem as to liability for expenses of receivership, see notes: 68 A.L.R. 878 (I930), 2I Col. L. Rev. 466 (Ig2I), 2I Harv. L. Rev. 529 (IgO8).

I7 Supra note 2.

${ }^{18}$ Tardy's Smith on Receivers (I920), $\$ \S$ I5, 25, 240; I Wiltsie, Foreclosure of Mortgages (4th ed. I927), § 564. See Ill. Statutes, Smith-Hurd (I933), c. 22:55. 
jurisdiction such as New York as it is in "title" jurisdictions." A receiver is frequently appointed after a foreclosure sale, although the mortgagee's right to possession is terminated by the sale..$^{20}$

If the appointment of the receiver were really the equivalent of the entry by the mortgagee into possession, the right of tenants to terminate their leases upon the appointment of a receiver would almost certainly have appeared in the English cases where doctrines of privity are applied with great strictness. ${ }^{2 x}$ Under the traditional English and Irish practice, however, the mortgagor's tenants are required, as a matter of course, to attorn to the receiver and, if they refuse, are committed for contempt of court. ${ }^{22}$ If it is necessary to distrain for rent before attornment the court orders the receiver to proceed in the name of the mortgagor. ${ }^{23}$ Likewise, even before attornment the receiver may take advantage of statutes designed to protect landlords. ${ }^{24}$ Furthermore, there is considerable authority in both England and America to the effect that the receiver is entitled to arrears of rent which, though accruing before his appointment, had not been collected by the mortgagor prior to the receivership..$^{25}$

The fact that the fund collected by the receiver is usually awarded to the mortgagee who institutes the receivership does not justify the conclusion that the receiver's position is substantially that of a mortgagee in possession. In "lien" jurisdictions, such as New York, in which the mortgagee has no right to possession, the surplus collected by the receiver is awarded to the mortgagee to satisfy the deficiency remaining due after the foreclosure sale, just as in the jurisdictions in which the mortgagee is en-

${ }^{39}$ See, for example, Hollenbeck v. Donnell, 94 N.Y. $34^{2}$ (1884), and Post v. Dorr, 4 Edw. Ch. (N.Y.) 4 I2 $(1844)$.

${ }^{20}$ Haas v. Chicago BIdg. Society, 89 Ill. 498 ( 1878 ); O'Brian v. Fry, 82 Ill. 274 (I876).

${ }^{2 x}$ See Dunlop v. Selfridge, [rgr5] A.C. 847; Pound, Spirit of the Common Law (I92x), 22 et seq.

22 Davis v. Duke of Marlborough, 2 Swanst. 108 (Ch. I818); Seton, Decrees (2d ed. 1854), 539; 2 Daniell, Chancery Practice (6th Am. ed. I894), * I74I.

${ }_{23}$ Pitt v. Snowden, 3 Atk. $75^{\circ}$ (I752); Hughes v. Hughes, I Ves. I6I (I790); Seton, Decrees (2d ed. I854), 540; Fisher and Lightwood, Mortgages (7th ed. r93r), 37r.

${ }^{24} \mathrm{Cox}$ v. Harper, [Igro] I Ch. 480 in which without attornment receiver was held to be a "landlord" of mortgagor's tenant for the purposes of Landlord and Tenant Act (I7\%) and therefore entitled to demand rent in arrears from execution creditor of mortgagor.

${ }_{25}$ Codrington v. Johnstone, I Beav. 520 (I838); Russell v. Russell, 2 Ir. Ch. R. 574 (r853); Lofsky v. Maujer, 3 Sand. Ch. (N.Y.) 69 (1845); note, 33 Col. L. Rev. I2Ir (I933); contra: Steward v. Fairchild-Baldwin, 9I N.J. Eq. 86, I08 Atl. 30r (I9rg); cf. St. Louis Union Trust Co. v. Wabash, C. \& W. R. Co., 258 Ill. App. 9 (I930); Paramount Bldg. \& Loan Assn. v. Sacks, Io7 N.J. Eq. 328, I52 Atl. 457 (I930). 
titled to possession. ${ }^{26}$ Yet in New York the receiver cannot be in any sense a mortgagee in possession, since first, mortgagees are not entitled to possession and secondly, the receiver is bound by the mortgagor's leases.7 The fact that the mortgagee is awarded the fund shows not that the receiver occupies substantially the position of a mortgagee in possession, but rather that the surplus in question is a portion of the security available for the satisfaction of the mortgagee's claim. The fund is awarded ultimately to the mortgagee not because it has been collected by his representative, the receiver, but because the fund is a portion of the security pledged by the mortgagor, and the proceeds of the sale have been insufficient to satisfy the mortgage debt. The appointment of the receiver, however, is not an adjudication that the mortgagee's security includes rents and profits, and it is not equivalent to an award to the mortgagee of the fund to be collected by the receiver. The distribution of the fund is not determined until the termination of the litigation. ${ }^{28}$ It will be awarded to a mortgagee only if the court determines that rents and profits, pending foreclosure, are a portion of the mortgagee's security. If, as is the rule in a number of jurisdictions, the court concludes that rents and profits are in no sense security for satisfaction of the mortgage debt, the fund will be awarded not to a mortgagee but to the holder of the equity of redemption. ${ }^{29}$ Even though rents and profits are, in the jurisdiction, a portion of the mortgagee's security, the fund will not be given to the mortgagee who instituted the receivership, unless he establishes that his mortgage is superior to that of other parties to the litigation, and that the suit has resulted in a sale leaving a deficiency. ${ }^{30}$ If his mortgage has been satisfied, or if he dismisses his suit, or if he obtains a decree of strict foreclosure he is not entitled to any of the fund. ${ }^{3 x}$ The fact that he instituted the receivership does not give him any priority over other parties to the litiga.-

${ }_{26}$ Post v. Dorr, 4 Edw. Ch. (N.Y.) 4 r2 (I847); Astor v. Turner, Ir Paige (N.Y.) 436 (I845). ${ }^{27}$ Supra note 8.

${ }_{28}$ New Jersey Title Guarantee \& Trust Co. v. Cone \& Co., 64 N.J. Eq. 45,53 Atl. 97 (Igo2); Last v. Winkel, 86 N.J. Eq. 356; 97 Atl. 96I (rgI6); I Wiltsie, Foreclosure of Mortgages (4th ed. I927), §606.

${ }_{29}$ Elmira Mechanics Society v. Stanchfield, I60 Fed. 8II (C.C.A. 8th I908); Wagar v. Stone, 36 Mich. 364 (I877); Marshall Ilsley Bank v. Cody, 76 Minn. Ir2, 78 N.W. 978 (I899); First National Bank of Aberdeen v. Cranmer, 42 S.D. 404, 175 N.W. 88x (1920); Gerber v. Heath, 92 Wash. 5I9, I59 Pac. 69I (IgI6).

${ }^{30}$ Desiderio v. Tadonisi, II5 Conn. 652, I63 Atl. 254 (1932); Cross v. The Will County National Bank, I77 Ill. 33, 52 N.E. 322 (I898); note, however, terms of order of appointment.

3t Desiderio v. Iadonisi, ${ }_{115}$ Conn. 652, 163 Atl. 254 (1932); Corcoran v. Witz, 252 Ill. App. 473 (1929). 
tion, since the receiver acts in the interests of all parties to the litigation as their titles are ultimately determined by the court. ${ }^{32}$ To this rule there is but one exception, namely, that the institution of the receivership may give a junior lienholder a better claim to rents and profits collected by the receiver than a senior lienholder who fails promptly to intervene in the receivership. The senior lienholder, even though he later intervenes, obtains no claim to that portion of the rents and profits collected by the receiver prior to the intervention. ${ }^{33}$ The reason for this advantage is not that the receiver is the representative of the petitioning mortgagee-he cannot be because other parties to the receivership including the mortgagor may share in the fund-but rather because a mortgagee who has done nothing to preserve the security should not be in a better position than he would have been had the mortgagor continued in possession. Even this advantage is denied the petitioning mortgagee in some jurisdictions in which the fund is distributed among parties to the suit and interveners in order of the priority of their securities. ${ }^{34}$

It would seem, then, that even though the receiver may avoid the mortgagor's leases and even though the fund that he accumulates is normally applied on the mortgage debt the position of the receiver is not substantially that of a mortgagee in possession and that therefore the decisions that a mortgagee in possession cannot affirm the mortgagor's leases are not applicable to receiverships.

Even were the analogy closer, the rule that a mortgagee in possession cannot affirm the mortgagor's leases should not be extended beyond the limits required by the doctrine of stare decisis and should not be applied to receivership cases. The expediency of the rule of want of privity as applied to mortgage cases is most questionable. Though it may not be desirable to permit strangers coming in under a paramount title to affirm the leases of tenants who chance to be in possession of land, the position of the mortgagee is quite different. Though the mortgagee is entitled to possession, the mortgagor continues to have a substantial interest in the premises. If the tenants are permitted to repudiate their leases, the burden will fall not merely upon the mortgagee but upon the mortgagor or his assignees. It should be noted that the want of privity doctrine was extended to the mortgage cases only after a great struggle and in the face of a line of cases holding that the mortgagee might by giving notice affirm the mortgagor's

${ }_{32}$ Cross v. The Will County National Bank, I77 Ill. 33, 52 N.E. 322 (I898); New York Title Guarantee \& Trust Co. v. Cone \& Co., 64 N.J. Eq. 45, 53 Atl. 97 (IgO2).

33 Bermes v. Kelley, 108 N.J. Eq. 289, 154 Atl. 860'(I93I).

34 Bergin v. Robbins, rog Conn. 329, I46 Atl. 724 (I929). 
leases. ${ }^{35}$ This extension of the rule might have been justified as an extreme measure for the protection of the mortgagor by inducing the mortgagee not to assert his legal right to possession. This reason is not applicable to the receivership cases, since the mortgagor is amply protected by the rules restricting the appointment of receivers and, as we have seen, the rule has not yet been extended to them. In England the rule has all but been abolished by statute. ${ }^{36}$ In view of the disastrous consequences of the application of the rule to the mortgagor and his assignees and, in view of the increased difficulties of management, which the rule will thrust upon the courts if it is extended to the receivership cases, the desirability of limiting the doctrine rather than extending it seems obvious. It is not surprising, therefore, that the New Jersey Chancery Court recently rejected a tenant's plea based upon this theory and described it as "both novel and startling." 37

It would seem, then, even though a receiver is not bound by the mortgagor's leases and even though the mortgagee may ultimately get the fund collected by the receiver, that the tenants' first argument to justify their repudiation-want of privity-is unsound.

\section{UNEAIRNESS}

The second argument of the tenants is that upon equitable principles of fairness if the receiver may repudiate the mortgagor's leases, the tenants should have a corresponding privilege. As Mr. Justice Crouch stated the argument in his dissenting opinion in Holmes v. Gravenhorst: ${ }^{38}$

- "The actual basis of the decision in the Prudence Company case, as it seems to me, was not the stern logic of the doctrine of possession, but rather the equitable consideration that the asserted right of the receiver to get occupational rent, when that was higher than the reserved rent, was not paralleled by reciprocal right in the tenant to pay only occupational rent when that was lower than the reserved rent."

The question is whether to permit the receiver and not the tenants to affirm or disaffirm the leases is so inequitable that the chancellor should not be a party to it. The experience of chancery with the notion that equality is equity and its application in the want of mutuality cases has been so un-

${ }_{35}$ Pope v. Biggs, 9 B.\& C. 245 (K.B. I829); Waddilove v. Barnett, 4 Dowl. 347 (K.B. I835); Brown v. Storey, I Man. \& G. II 7 (Co. Pls. I84o); Underhay v. Read, 20 Q.B.D. 209 (x887); cf. Evans v. Elliot, 9 Ad. \& El. 342 (K.B. I838); Towerson v. Jackson, [I8gr] 2 Q.B. 484 . I Tiffany, Landlord and Tenant (IgI2), $\$ 73 \mathrm{a}(6)$.

${ }^{36} 44 \& 45$ Vict. c. $4 \mathrm{I}, \S$ I8 now replaced by I $_{5}$ Geo. V. c. $20, \S 99$.

37 Walgreen v. Moore, I73 Atl. 587 (N.J. I934).

${ }^{38}$ Holmes v. Gravenhorst, 263 N.Y..148, r57, x88 N.E. 285,288 (1933). 
fortunate that one should be extremely skeptical of suggestions for its extension. ${ }^{39}$ Its application to this case seems peculiarly inappropriate.

-If the tenant's plea is allowed, the purposes of the receivership will be very largely frustrated. Assets will be dissipated rather than preserved and the task of administration will be rendered much more difficult..$^{\circ} \mathrm{It}$ will result in loss not merely to mortgagees but in every case to the mortgagor and assignees of the mortgagor. ${ }^{4 \mathrm{x}}$ At first thought this economic waste with the inevitable hardship imposed upon those least able to bear it might seem justified as the price of rescuing the tenant from an intolerable position. But if one considers the tenant's position carefully, one finds that it is not particularly harsh. In the first place, the receiver's privilege of rejecting the mortgagor's leases must be exercised promptly upon his appointment..$^{2} \mathrm{He}$ is, of course, allowed a sufficient period within which to form an intelligent opinion of the merits of the lease, but once that period has elapsed the receiver's privilege of rejecting the lease is lost and thereafter the lease is as binding upon the receiver as one which he has negotiated personally. Even though the receiver rejects the lease promptly upon his appointment the tenant cannot be compelled to continue to pay rent upon any basis other than the terms of his old lease. If he and the receiver cannot come to terms, he may vacate the premises and avoid future liability for the premises..$^{43}$ On the other hand, if the receiver fails to reject the lease promptly the tenant continues to enjoy the premises strictly in accord with the terms of his bargain with the mortgagor.

Secondly, the position of the tenant is the consequence of a risk which he voluntarily assumed when he took the lease. In some cases the lease is by its very terms expressly subordinate to the mortgage. The tenant knew that his right to occupy the premises under the lease was contingent upon satisfaction of the mortgage and with this knowledge he entered into the premises. If the lease is not in terms subordinate to the mortgage the

39 Ames, Lectures on Legal History (I9I3), 370 et seq.; Lewis, Present Status of the Defence of Want of Mutuality in Specific Performance, $5 \mathrm{I} \mathrm{Am.} \mathrm{Law} \mathrm{Reg.} \mathrm{(O.S.)} 59 \mathrm{I}$ (I903); Pomeroy, Specific Performance of Contracts in Illinois, I Ill. Law Bul. II7, I28 (I9I8).

$4^{10}$ For an extreme statement of this point see Walgreen v. Moore, I73 Atl. 587 (N.J. 1934).

47 The mortgagor will be damaged not only because he loses a valuable lease, but also because he will be liable for breach of covenant to the tenant who is evicted. Mack v. Patchin, 42 N.Y. I67 (1870); Ganz v. Clark, 252 N.Y. 92, 169 N.E. Ioo (1929); B. F. Avery \& Sons v. Kennerly, I2 S.W. (2d) I40 (Tex. 1929).

42 Central Republic Trust Co. v. 33 South Wabash Bldg. Corp., 273 Ill. App. 380 (1934).

43 Sager v. Rebdor Realty Corp., 230 App. Div. ro6, 243 N.Y. Supp. 3 I4 (1930); MonroKing \& Gremmels Realty Corp. v. 9 Avenue-3r Street Corp., 233 App. Div. 4or, 253 N.Y. Supp. 303 (I93I). 
predicament of the tenant is the result of his willingness to take a lease without investigating the lessor's title. Had he examined the title he would have discovered the incumbrance. If he did not care to examine the title, he might easily have protected himself by insisting upon a lease in which a breach of a covenant against incumbrances was made a ground for termination of the lease. Since he did not take these precautions, he should not be heard to say that he did not assume the risk of possible defects in his lessor's title, and should not be granted relief from his bargain. The real basis of the tenant's plea is that he has taken a lease which has proved unprofitable. Real estate values have gone down and not up, and consequently the tenant seizes upon the cry of hardship and the technical plea of want of privity to avoid the consequences of his error in judgment.

It is not, therefore, surprising to find that the cases indicate that the plea of the tenant will be rejected by the courts. Though there does not seem to be any clear-cut decision on the question, English and Irish cases and the opinions of English commentators point to this conclusion. ${ }^{44}$ In accord are the decisions in analogous types of cases. First is the wellknown rule that a tenant in possession of the premises cannot, unless he can establish a breach of covenant, which is an express condition precedent; avoid his lease because of a defect in his landlord's title, even though this defect is one which may at any time be asserted against him. ${ }^{45}$ In these cases the stranger may obtain the privilege of affirming or disaffirming by obtaining an assignment from the lessor. When there is the wellestablished rule allowing the receiver of a corporation or the trustee in bankruptcy a reasonable period within which to determine whether to adopt or reject leases of the insolvent corporation or bankrupt. $4^{6}$ Also inconsistent with the tenant's plea is the rule developed in foreclosure cases in New York and other lien jurisdictions permitting the mortgagee to elect to adopt or disaffirm the mortgagor's leases. If the mortgagee desires to adopt the mortgagor's lease, he does not join the tenant in the foreclosure proceedings and does not obtain a decree of foreclosure against the tenant. The purchaser at the sale, who is usually a mortgagee, may enforce the lease as the assignee of the reversion. ${ }^{47}$ If, however, the mort-

44 Supre notes 22, 23, 24 and 25. See also Walgreen v. Moore, I73 Atl. $5_{7} 7$ (N.J. r934).

45 Bigelow, Estoppel (6th ed. I913), 547 et seq.; I Tiffany, Landlord and Tenant (I9I2), \& 78.

${ }^{6} \mathrm{Clark}$, Foley, and Shaw, Adoption and Rejection of Contracts and Leases by Receivers, 46 Harv. L. Rev. IIII (I933); note, 3I Col. L. Rev. 297 (I93I).

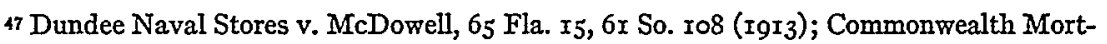
gage Co. v. De Waltoff, 135 App. Div. (N.Y.) 33 (rgog); Metropolitan Life Insurance Co. v. Childs Co., 230 N.Y. 285, r30 N.E. 295 (x92I); Markantonis v. Madlan Realty Corp., 262 N.Y. 354 , I86 N.E. 862 (I933); Ex parte Owens, roo S.C. 324,84 S.E. 875 (Igr5).

Contra: McDermott v. Burke, I6 Cal. 580 (I860) (dictum since lessee took his lease after 
gagee desires to avoid the mortgagor's lease, he makes the tenant a party to the suit and obtains a decree of foreclosure against him. Then as purchaser at the sale the mortgagee may evict the tenant. This rule Mr. Justice Crouch apparently overlooked in his explanation of the Prudence case. This privilege of the mortgagee shows, it is submitted, that the New York rule that the receiver is bound by the mortgagor's leases is to be justified on the ground that in New York the mortgagee's security is limited to the rents which actually accrue under the mortgagor's leases and not upon the ground of preventing hardship to the tenant.

Likewise inconsistent with the tenant's plea is the rule that a mortgagee may, by obtaining the co-operation of the mortgagor, have the privilege of adopting or rejecting the mortgagor's leases. As assignee of the reversion he will be entitled to the privileges of a landlord; $4^{8}$ as mortgagee he will not be bound by them. In view of these well established lines of decisions it seems that the courts will not be persuaded by the tenant's plea of fairness.

In summary, then, the solution of the problems of the essay seems simple: the receiver may, and in the typical case should adopt the mortgagor's leases. Only in the exceptional case in which the continuance of these leases endangers the mortgagee's security may he reject them. On the other hand, neither the appointment of the receiver nor the privilege of the receiver to reject the mortgagor's leases gives the tenants the right to repudiate their leases.

the suit was instituted and was therefore bound by the decree under the doctrine of $l$ is pendens); Downard v. Graff, 40 Iowa 597 ( 1875 ), (but cf. First Trust Joint Stock Land Bank of Chicago v. Ingels, 25 I N.W. 630 (Towa, I934)); Dolese v. Bellows-Claude Neon Co., 26r Mich. 57, 245 N.W. 569 (1932). For a criticism of this line of cases see 3 Tiffany, Real Property (2d ed. I920), 2700 et seq.; note 32 Mich. L. Rev. II9 (I933).

In a "title" jurisdiction even though the lessee has not been foreclosed, the purchaser at the sale should not be bound by these leases since he succeeds to the rights of the mortgage. Cf. however, Eliveeay Newspaper Assn. v. Wagner Market Co., r1o N.J.L. 577, r66 Atl. 332 (1932) (dictum). The court may, however, when the mortgagee will not be prejudiced, order a sale subject to the lease; in such case the purchaser is, of course, bound by the lease. See Western Union Tel. Co. v. Brown and Randolph Co., ${ }_{54}$ Ga. 229, Ir4 S.E. 36 (1932).

For a discussion of the problem see notes: I4 A.L.R. $66_{4}$ (I92I); Ann. Cases I9r ${ }^{A}$ A 397 (IgI5); 42 Harv. L. Rev. 280 (I928); I3 Col. L. Rev. 553 (I9I3).

$4^{8}$ Chicago City Bank and Trust Co. v. Walgreen Co., 272 Ill. App. 434 (I933); International Paper Co. v. Priscilla Co., 28I Mass. 22, I83 N.E. 58 (I932). 